\title{
発電停止を必要としない沈砂池土砂排除用渦動 排砂管に関する研究 \\ STUDY OF SAND FLASHING VORTEX TUBE FOR THE SAND BASIN NEEDLESS STOPPING GENERATION
}

\author{
熊谷 洋 ${ }^{1}$, 小田桐悦郎 ${ }^{2}$ \\ Yo KUMAGAI, Etsuro ODAKIRI
${ }^{1}$ 正会員 工修 東北電力株式会社 送変電建設センター（旧研究開発センター土木研究 $G$ ) ₹ 980-0811 仙台市青葉区一番町 3 丁目 7 番 23 号明治生命仙台ビル $7 \mathrm{~F}$
東北電力株式会社 研究開発センター土木研究 $G$
干 980-0841 仙台市青葉区中山 7 丁目 2 番 1 号

A sand basin installed in the hydroelectric plant is designed so as to be able to settle sand beyond a grain size so that degradation of discharge ability of the water channel and abrasion of water pressured pipe and turbine can be restrained. However, performance of the power plant is lowered when sand flowing in a sedimentation basin is beyond the designed value because of frequent sand removal works. Instead of the conventional work using sand removal gate, we propose here a vortex tube method with which electric generation operation is not interrupted during sand removal work, showing some related design methods.

Key Words: Sand basin, Vortex tube, and Hydro power plant, Sand flash

\section{1.まえがき}

一般に流れ込み式水力発電所には，取水口下流に 沈砂池が設けられ, 導水路・水槽・水車等への土砂流 入を防止している。

沈砂池は，取水口から水路内に流入する土砂量を 推定し, 沈砂池内で任意の粒径以上の土砂が沈降・滯 留・排除できるよう計画され, 導水路の通水能力の低 下や水圧鉄管・水車の摩耗等を防止する仕組みと なっているが, 沈砂池内への流入土砂が計画值を超 える場合には, 設備の機能維持のための排砂作業頻 度が高くなり, 発電所の設備利用率を低下させるこ ととなる。

本研究では, 従来の排砂門による排砂作業に替わ る方法として, 排砂作業のために発電停止を必要亡 しないシステムである親水路付渦動排砂管を提案し, 親水路付渦動排砂管の設計手法の提案を行った。

\section{2. 䙿水路付渦功排砂管の原理}

親水路付渦動排砂管は, 管の一部にある幅の狭い久 リットから土砂濃度の高い底面付近の水を取水し, これ を刎ッからの流入に伴って生ずるらせん流豆と管軸方 向すなわち親水路からの流れにより生ずる壁面噴流 およびらせん流を利用して土砂を排出するものであ る。親水路付渦動排砂管の排砂原理を図-1に示す。

親水路付渦動排砂管は図-1で示す通り, 杊忆管と親 水路の大きく 2 つに分けられる。親水路は, 形状的に 祅管に対して斜め上方に立ち上げかつ偏心して取 り付けられるのが特徵である。親水路管径は, 刏管 内で壁面噴流およびらせん流の発生を促すため, 刏ッ

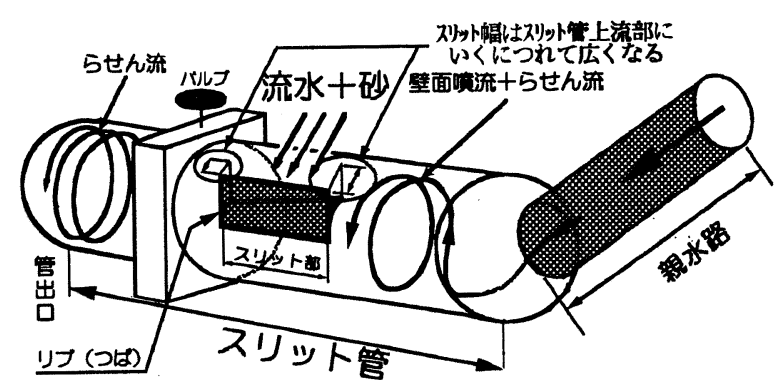

図-1＼cjkstart親水路付渦動排砂管の概略図 
管よりも細くなっている。杊师管は, 刏归全体から一 様に水を流入させるため, 刏㨽が则管上流部にい くほど広くなっている2)。また，らせん流の発達を促 進するため, 刏ッ管に図-1で示す通りリブを取り付け ている。親水路は刏忆管より管径を細く, 刏坆管に対 して偏心して取り付けられている。

また, 親水路付渦動排砂管は, 主に発電所沈砂池や 取水口前面に設けられることを前提にするため，親 水路付渦動排砂管の最適形状を検討する場合, 1)管の 入口に砂れきがつまらない,2)流入した土砂が管内に 堆積せず十分輸送される，3)排砂効率が良い，を考慮 する必要がある。

\section{3. 水理模型実験}

\section{(1)实磁譬圆}

今回の水理模型実験は, 花山発電所沈砂池内に設 置している親水路付渦動排砂管に対するもの り, 模型縮尺は $1 / 2$ とした。渦動排砂管の流れは, 重 力と慣性力に支配されることから，フルードの相似 則を用いた3次元模型により行った。原型と模型諸量 の縮尺比を表- 1 に示す。実験装置の概略図を図 -2 に 示す。図-3に親水路付渦動排砂管の概略を示す。レ イノルズ数は約 $1.0 \times 10^{5}$ であり，管路内の流れは十 分に乱流状態である。

\section{(2)实酸条件}

実験条件は，表-2に示す通りである。なお，杊管 の管径は $5 \mathrm{~cm}$, 水位条件は, $90 \mathrm{~cm}$ から $150 \mathrm{~cm}$ とした。 排砂試験で使用する土砂は $2 \mathrm{~mm}$ 小るいを通過したも のを用いた。

\section{(3)实験方法}

親水路付渦動排砂管の全流量および親水路からの 流入量は, 水位条件 $90 \mathrm{~cm}$ から $150 \mathrm{~cm}$ の間の約 $10 \mathrm{~cm}$ ピッチで測定を実施した。水位は, 図 - 2 に示す通り スリット管中心位置から水面までの距離とする。出 ロバルブを全開にした状態でそれぞれの水位に対応 するべく流量を䘞部水槽に流入させ, 水位変動が 落ちついた時点でマノメー夕を用いて水位を測定す る。流量は電磁流量計により測定した。

排砂確認試験も実施した。2 $\mathrm{mm}$ 小るいを通過した 土砂を用い，渦動排砂管内部に砂が管径の半分まで の高さに堆積し, さらに杊管の天端から视愔部全 体にわたり砂を約 $10 \mathrm{~cm}$ の厚さで堆積させた状態から 土砂の排砂の可否に関する試験を行った。排砂試験 の状況はビデオカメラを用いて記録した。

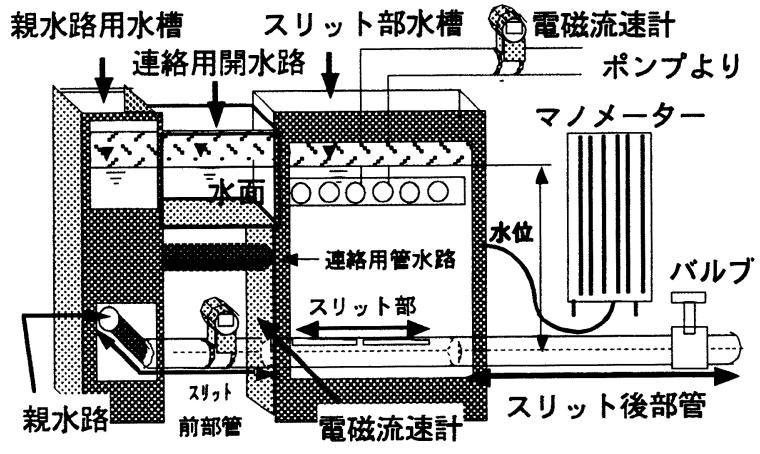

図-2＼cjkstart実験装置概略図

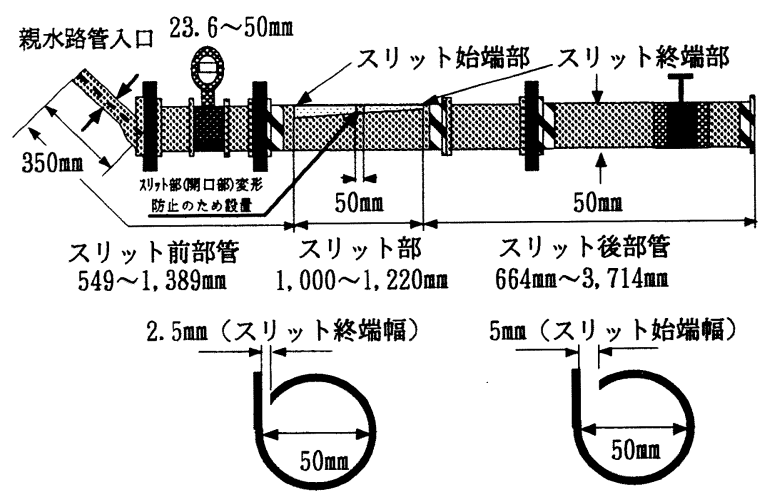

図-3 横から見た渦動排砂管の概略図

表-1 原型と模型諸量の縮尺比

\begin{tabular}{|c|c|c|}
\hline & & 要尺比 \\
\hline 長さ & $\mathrm{L}$ & $K_{L}=L_{P} / L_{m}=2$ \\
\hline 流遇 & $\mathrm{v}$ & $K_{V}=v_{p} / v_{m}=K_{L}(1 / 2)=1.414$ \\
\hline 流贯 & $Q$ & $K_{Q}=Q_{P} / Q_{m}=K_{L}(5 / 2)=5.657$ \\
\hline 䢂往 & $d$ & $K d=d_{p} / d_{m}=2$ \\
\hline 時的 & $t$ & $K t=t_{p} / t_{m}=K_{L}(1 / 2)=1.414$ \\
\hline
\end{tabular}

表-2 実験条件

\begin{tabular}{|c|c|c|c|c|c|}
\hline 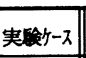 & 列》長 & 測定項目 & 親水路管径(mm) & $\begin{array}{c}Z_{1} \text { 卜前部管長 } \\
\mathrm{L}(\mathrm{m})\end{array}$ & 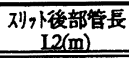 \\
\hline Case-1 & $1.0 \mathrm{~m}$ & $\begin{array}{c}\text { 親水路流量 } \\
\text { 全流量 }\end{array}$ & $\begin{array}{c}23.6,28.1 \\
36.1,42.1,50\end{array}$ & 1.389 & $\begin{array}{l}0.664 \\
2.168 \\
3.714\end{array}$ \\
\hline Case-2 & $1.22 \mathrm{~m}$ & $\begin{array}{c}\text { 親水路流量 } \\
\text { 全流量 }\end{array}$ & $\begin{array}{l}23.6,28.1 \\
36.1,42.1,50\end{array}$ & 1.351 & $\begin{array}{l}0.482 \\
1.986 \\
3.512\end{array}$ \\
\hline Case-3 & $1.0 \mathrm{~m}$ & 全流量 & $\begin{array}{c}23.6,28.1, \\
36.1,42.1,50 \\
\end{array}$ & 0.587 & 2.168 \\
\hline Case-4 & $1.22 \mathrm{~m}$ & 全流量 & $\begin{array}{c}23.6,28.1, \\
36.1,42.1,50\end{array}$ & 0.549 & 1.986 \\
\hline
\end{tabular}

\section{4. 流至係数およひ擩流力係数の考え方}

今回，水理模型実験から親水路流量および親水路 付渦動排砂管の全流量を電磁流速計を用いて測定し たが，これらの結果から親水路付渦動排砂管の流量 係数および掃流力などの物理量を求める方法につい て述へる。親水路付渦動排砂管から流出する全流量 $\mathrm{Q}$ total, 親水路流量 $\mathrm{Q}$ oya, 帅快らの流量 $\mathrm{Q}$ slit は, オリフィスの流量を求める式と同様に, 式(1), 式(2), 式(3)で表すことができる。

$$
\begin{aligned}
Q_{\text {total }} & =C_{\text {total }} \times a_{\text {total }} \times \sqrt{2 \mathrm{gH}} \\
Q_{\text {oya }} & =C_{\text {oya }} \times a_{\text {oya }} \times \sqrt{2 \mathrm{gH}}
\end{aligned}
$$




$$
Q_{\text {slit }}=\left(C_{\text {total }} \times a_{\text {total }}-C_{\text {ova }} \times a_{\text {oya }}\right) \times \sqrt{2 g H}
$$

$\mathrm{H}$ : 総落差 (水面～刏ッ卜管出口中心), $\mathrm{C}_{\text {oya }}$ : 親水路流 量係数, $\mathrm{C}_{\text {total }}$ : 全流量流量係数, $\mathrm{a}_{\text {oy: }}$ : 親水路管径断 面積, $\mathrm{a}_{\text {total }}$ : スリット後部管径断面積

親水路流入口から親水路と则ッ管との接合部付近 まで,すなわち親水路の動水勾配を求める。マニング の式より動水勾配は式(4)で表される。

$$
\mathrm{I}=\mathrm{n}^{2} \times \mathrm{R}^{-\frac{4}{3}} \times \mathrm{v}^{2}
$$

$\mathrm{n}:$ 親水路の粗度係数 $(\mathrm{n}=0.01), \mathrm{R}:$ 親水路の径深, $\mathrm{v}$ :親水路 管内平均流速

親水路内平均流速は, 径深を用いて式(5)となる。

$$
\mathrm{v}=\frac{Q_{\text {oya }}}{a_{\text {oya }}}=\frac{Q_{\text {oya }}}{\frac{\pi \mathrm{D}^{2}}{4}}=\frac{Q_{\text {oya }}}{4 \pi\left(\frac{D}{4}\right)^{2}}=\frac{Q_{\text {oya }}}{4 \pi \mathrm{R}^{2}}
$$

$\mathrm{D}$ :親水路管径，径深 $\mathrm{R}=\mathrm{D} / 4$ （円管の場合）

式(4), 式(5)から動水勾配 I が求められる。

$$
\mathrm{I}=\frac{\mathrm{n}^{2} \mathrm{Q}_{\mathrm{oya}}^{2}}{16 \pi^{2} \mathrm{R}^{\frac{16}{3}}}
$$

親水路の掃流力は式(7)で表される。

$$
\tau=\rho \mathrm{gR} \mathrm{I}=\rho \mathrm{gR} \frac{\mathrm{n}^{2} \mathrm{Q}_{\mathrm{oya}}^{2}}{16 \pi^{2} \mathrm{R}^{\frac{16}{3}}}=\frac{\rho \mathrm{g} \mathrm{n}^{2} \mathrm{Q}_{\mathrm{oya}}^{2}}{16 \pi^{2} \mathrm{R}^{\frac{13}{3}}}
$$

式(2)を式(7)に代入し，整理すると式(8)になる。

$$
\tau=\frac{\rho g n^{2}}{16 \pi^{2} R^{\frac{13}{3}}}\left(C_{\text {oya }} \times a_{\text {oya }} \sqrt{2 g h}\right)^{2}=\frac{2 \rho g^{2} n^{2} C_{\text {oya }}^{2} a_{\text {oya }}^{2}}{16 \pi^{2} R^{\frac{13}{3}}} H
$$

式(8)は, 親水路から流入する水流により生ずる掃 流力を表す。親水路の掃流力の比例係数を掃流力係 数之定義し，掃流力係数 $\mathrm{C}^{\prime}$ 之置いて式(8)を整理する と, 式(9)で表される。式(9)より, 親水路の掃流力は, 水深 $\mathrm{H}$ に比例することがわかる。

$$
\left.\tau=\frac{2 \rho \mathrm{g}^{2} \mathrm{n}^{2} \mathrm{C}_{\text {oya }}{ }^{2} \mathrm{a}_{\text {oya }}^{2}}{16 \pi^{2} \mathrm{R}^{\frac{13}{3}}} \mathrm{H}=\mathrm{CH} \mid \mathrm{C}^{\prime}=\frac{2 \rho \mathrm{g}^{2} \mathrm{n}^{2} \mathrm{C}_{\text {oya }}{ }^{2} \mathrm{a}_{\text {ory }}{ }^{2}}{16 \pi^{2} \mathrm{R}^{\frac{13}{3}}}\right)
$$

\section{5. 実酸䊅果}

\section{(1) H - O特性}

杊開口部の断面積および親水路管径が一定の場 合, 親水路付渦動排砂管から流出する水の量は重力 に支配されるためオリフィス同様, 流量は水深の $1 / 2$ 乗に比例する。図-4, 図-5に全流量および親水路流 量の H - Q 特性を示す。 L1 は杊ッ瑐部管長, L2 はス刏

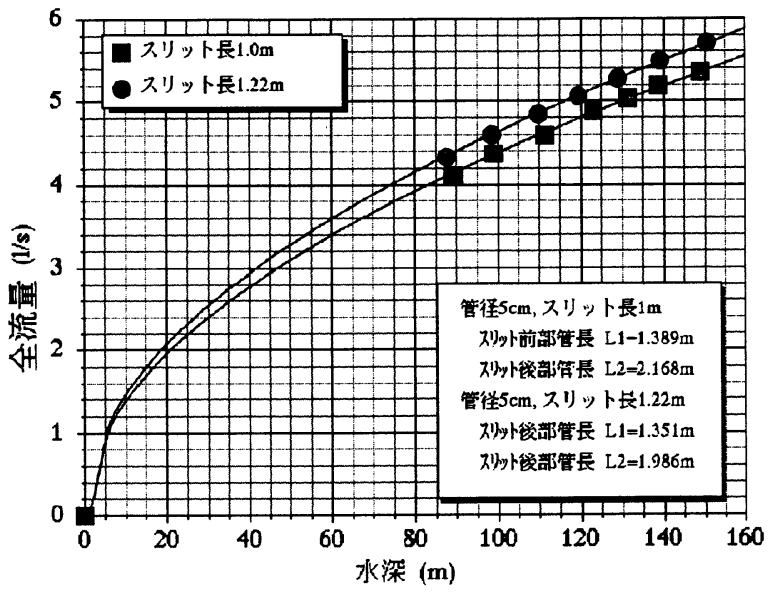

図-4 H-Q特性（全流量）

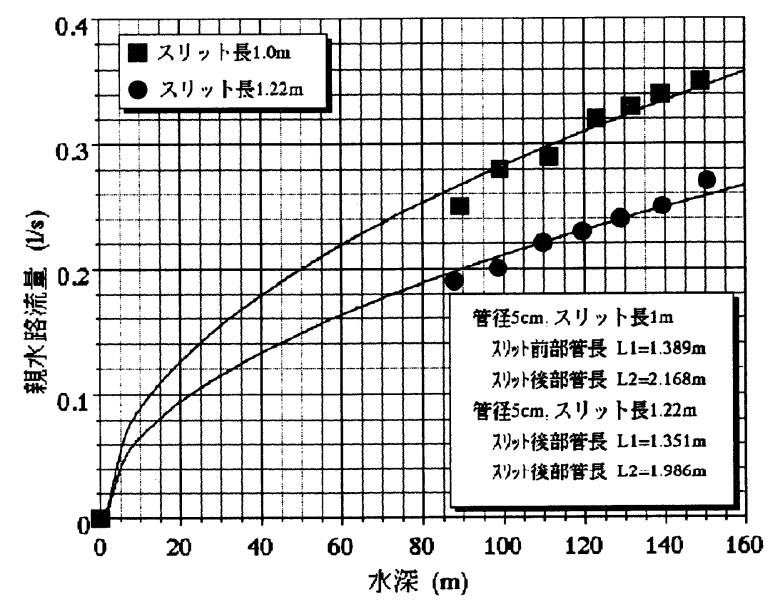

図-5 H-Q特性（親水路流量）

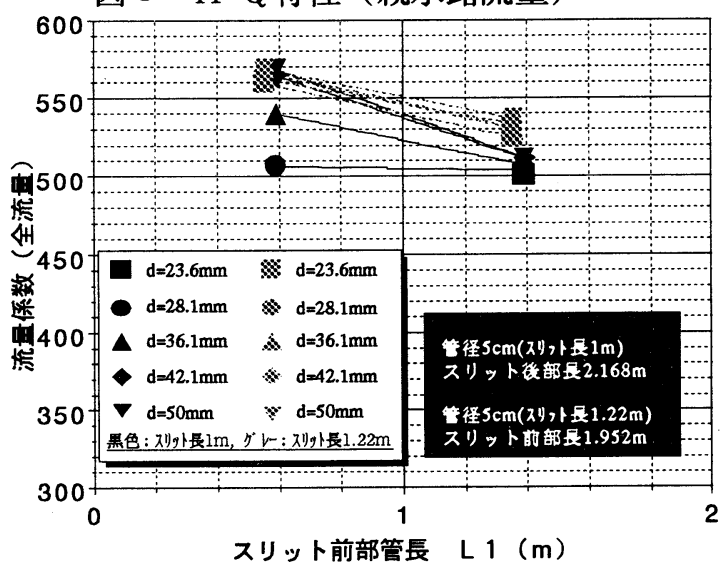

図-6 スリット前部管長の影響

卜後部管長である。全流量および親水路流量ともに, 流量が水深の $1 / 2$ 乗に比例していることがわかる。

\section{(2)流且俰数へのスリット前部管長の影要}

今回の水理模型実験で刏ッ瑐部管長が短いケース は, 電磁流量計を設置不可能であったため, 全流量で 则ッ前部管長の影響評価を実施した。

図-6に刈ッ長 $1 \mathrm{~m}, 1.22 \mathrm{~m}$ の場合における列瑐部 管長の影響を示す。杊瑐部管長が短くなると全流量 流量係数が増加する。しかし, 杊ッ長が $1 \mathrm{~m}$ で親水路 管径が28.1mmの場合则外前部管長短縮に伴う全流量 
係数の増加はあまり見られなかった。

\section{(3)流吾係数へのスリフト後部管長影需}

図-7に刈轪部管長の違いによる全流量の流量係 数, 図-8に则後部管長の違いによる親水路流量の 流量係数を示す。全流量の流量係数は, 刏ッ後部管長 が0.664mから3.714mに増加するにつれてほぼ線形的 に滅少する。親水路の流量係数は, スリッ後部管長が $0.664 \mathrm{~m}$ と $3.714 \mathrm{~m}$ を比較した場合, スリット後部管長 $3.714 \mathrm{~m}$ の流量係数は刏ッ後部管長が $0.664 \mathrm{~m}$ の流量係 数と比べて約 2 割小さい程度である。したがって, ス リッ後部管長は, 親水路流量係数に与える影響は小さ いと考えられる。

\section{(4)流旦俰数への親水路管径野}

図-9に親水路管径の違いによる親水路流量の流量 係数を示す。親水路の流量係数は, 親水路管径 $28.1 \mathrm{~mm}$ の場合，最大になることがわかる。

\section{(5)擩流カへのスリタト後部管長影}

杊归部管長の影響の検討を, 式(9)で定義した掃 流力係数で説明を行う。図-10に示す通り, 刏ッ後部 管長が短いほど掃流力係数は大きくなり, 则ッ後部管 長が短くなるほど掃流力係数の増加する割合が大き くなることがわかる。

\section{(6)㧎流カへの䙿水路管径およびスリタト長の影要}

図-11に列悵 $1 \mathrm{~m}$, 刏师管径 $5 \mathrm{~cm}$ の場合の親水路入 口部管径と则後部管長ごとの掃流力係数の関係を 示す。図-11より, 全ての则後部管長において親水 路管径が $28.1 \mathrm{~mm}$ の場合に掃流力係数が最大になっ た。したがって, 親水路管径 $28.1 \mathrm{~mm}$ の場合, 排砂効 率が最大であることがわかる。

図-11に管径 $5 \mathrm{~cm}$ の場合の杊悵と掃流力係数との 関係を併せて示す。杊ッ長が 2 割増加すると, 図-8よ り親水路流量係数は約 2 割減少する。式(9)より掃流 力係数は親水路流量係数の 2 乗に比例することから, 掃流力係数は約 4 割減少する。このことから, 刏ッ長 は，親水路鉛直立ち上げ部と则笹管の接合部掃流力 に与える影響が極めて大きく，親水路付渦動排砂管 の性能を決定する要因になると考えられる。

\section{(7)措砂機能確思}

表-3に排砂試験結果を示す。排砂試験の結果, 親 水路管径 $28.1 \mathrm{~mm}$ の場合, 最も効率よく排砂可能で あった。理由は次の通りである。

a. 親水路管径 $28.1 \mathrm{~mm}$ の場合と比較して親水路管径と 杊ッ管径の比率が大きくなると親水路側からの流入

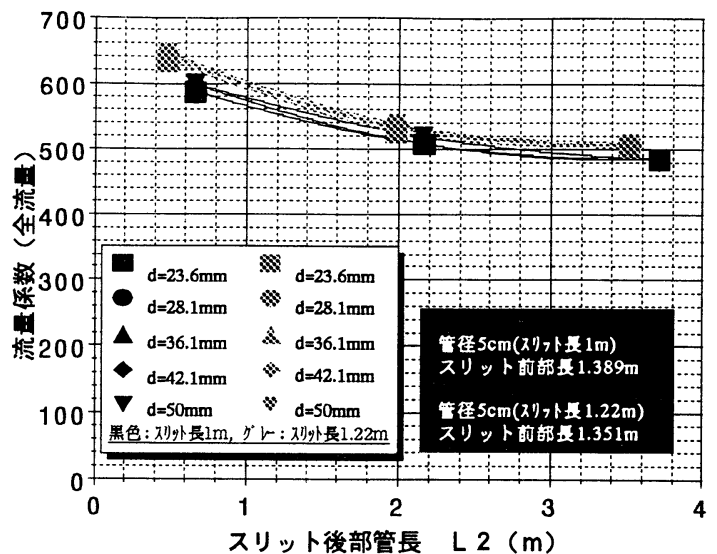

図-7 スリット後部管長と流量係数（全流量）

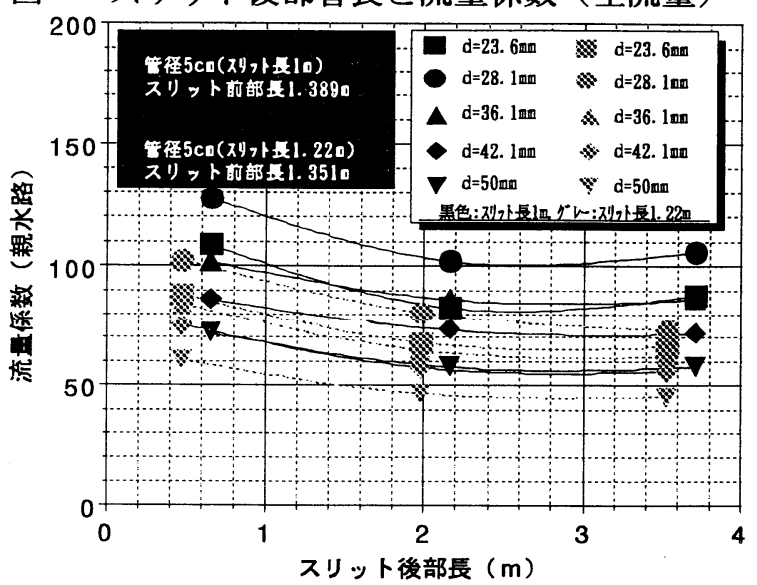

図-8 スリット後部管長と流量係数（親水路）

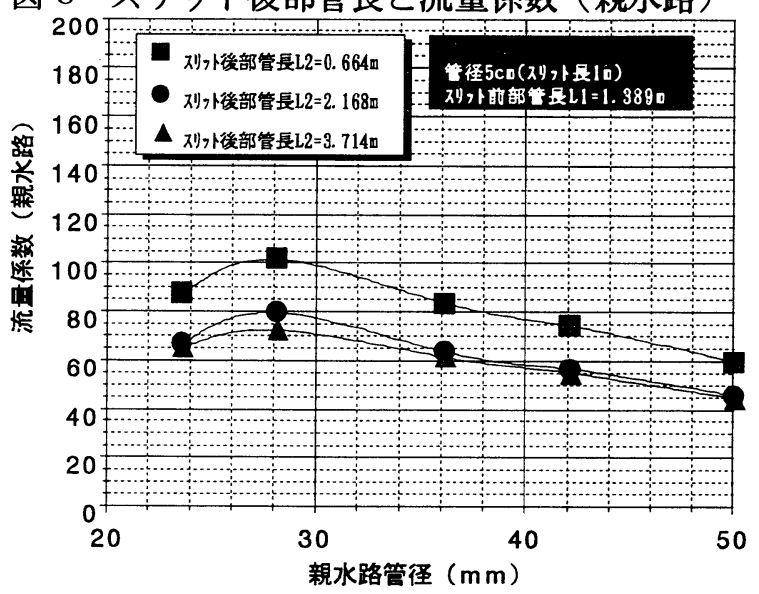

図-9＼cjkstart親水路管径亡流量係数（親水路）

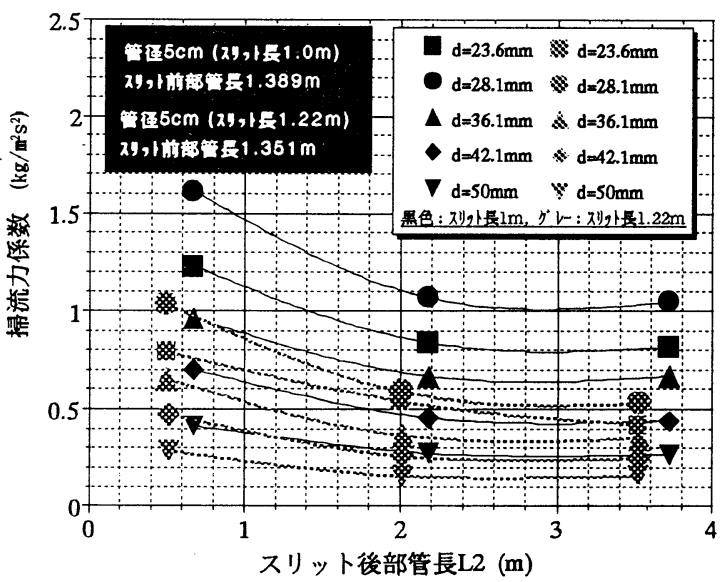

図-10 ㅈ川後部管長と掃流力係数 
によるらせん流の形成ができないが，親水路管径 $28.1 \mathrm{~mm}$ の場合, うまくらせん流が形成されている。 b. 親水路管径 $28.1 \mathrm{~mm}$ の場合, 図 -9, 図-11より流量 係数および掃流力係数の值が最大になる。すなわち, らせん流の生成がピークに達していると考えられる。

また, 址悵を $1.22 \mathrm{~m}$ の場合, どの親水路管径に対 しても完全に土砂を排砂することはできなかった。

これは, 刏ッ $1.22 \mathrm{~m}$ の場合, 刏ッ始端部から $20 \mathrm{~cm}$ ま での間において十分な水の流入が行われないため, その区間においてらせん流の発達が十分でなく，土 砂を排砂するのに十分な掃流力が得られていない状 態であると考えられる。

例として表-3で灰色部分で示される箇所に関して 掃流力を計算した。帅外始端部における掃流力は式(9) から算出される。計算結果は以下の通りである。限界 掃流力はシールズの式から算出した。実験で使用し た土砂粒径 $2 \mathrm{~mm}$ の場合, 限界掃流力 $\tau$ *c $6.99(\mathrm{~kg} /$ $\mathrm{ms}^{2}$ )である。

a)刏ッ悵 $1 \mathrm{~m}$ :

$(\mathrm{n}=0.01$, 親水路流量係数は図 -9 より 101)

$\tau=\frac{2 \times 1000 \times 9.8^{2} \times 0.01^{2} \times 101^{2} \times\left(0.0281^{2} \times \pi / 4\right)^{2}}{16 \times \pi^{2} \times\left(\frac{0.0281}{4}\right)^{\frac{13}{8}}} \times 1.35$

$\fallingdotseq 1.4\left(\mathrm{~kg} / \mathrm{ms}^{2}\right)>0.99\left(\mathrm{~kg} / \mathrm{ms}^{2}\right)=\tau_{{ }_{*}} \longrightarrow$ 排砂する

b)对ッ悵 $1.22 \mathrm{~m}$ :

$(\mathrm{n}=0.01$, 親水路流量係数は図 -9 より 80$)$

$$
\tau=\frac{2 \times 1000 \times 9.8^{2} \times 0.01^{2} \times 80^{2} \times\left(0.0281^{2} \times \pi / 4\right)^{2}}{16 \times \pi^{2} \times\left(\frac{0.0281}{4}\right)^{\frac{18}{8}}} \times 1.35
$$

$\fallingdotseq 0.75\left(\mathrm{~kg} / \mathrm{ms}^{2}\right)<0.99\left(\mathrm{~kg} / \mathrm{ms}^{2}\right)=\tau$ *c $\longrightarrow$ 排砂しない

以上の結果からも排砂しないことが明らかである。

\section{6. 実験轺果のまとめ}

親水路付渦動排砂管の水理模型実験結果をまとめ ると, 以下の通りとなる。表 -4 に水深などの諸元が 各流量に与える影響の一覧を示す。

(1)全流量は水深の $1 / 2$ 乗に比例し, 全流量の流量係数 は, 杊後部管が増加するにつれて滅少する。

(2)親水路の流量係数は, 杊後部管長の影響をほとん ど受けない。

(3)親水路の流量係数は, 親水路管径が $28.1 \mathrm{~mm}$ の場合 最大となる。

(4)则悵が親水路の流量係数に与える影響は大きい。

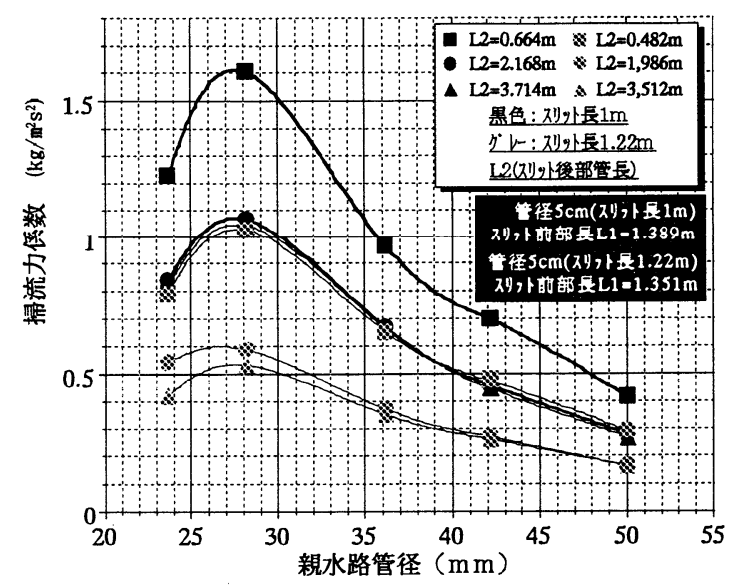

図-11 親水路管径と则ッ後部管長と掃流力係数

表-3 排砂試験結果

\begin{tabular}{|c|c|c|c|c|c|c|c|c|c|}
\hline \multicolumn{2}{|c|}{ 제바트 } & \multicolumn{4}{|c|}{ スリット長1 m } & \multicolumn{4}{|c|}{ スリット長1. $22 \mathrm{~m}$} \\
\hline \multirow{3}{*}{\multicolumn{2}{|c|}{ 排琽状況 }} & \multicolumn{4}{|c|}{ スリット後部管長2. $168 \mathrm{~m}$} & \multicolumn{4}{|c|}{ スリット後部管長 $1.986 \mathrm{~m}$} \\
\hline & & \multicolumn{2}{|c|}{ 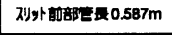 } & \multicolumn{2}{|c|}{ 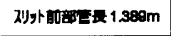 } & \multicolumn{2}{|c|}{ 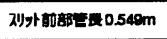 } & \multicolumn{2}{|c|}{ 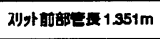 } \\
\hline & & 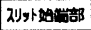 & 耕水路内 & גلy & 鴊水距内 & 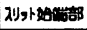 & 成水路内 & 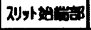 & 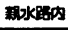 \\
\hline \multirow{5}{*}{ 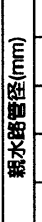 } & 23.6 & 0 & 0 & 0 & $x$ & $\Delta$ & $x$ & $\Delta$ & $x$ \\
\hline & 28.1 & O & 0 & $0 \%$ & 0 & $\Delta$ & $x$ & $\Delta$ & $x$ \\
\hline & 36.1 & 0 & 0 & 0 & $\Delta$ & $\Delta$ & $x$ & $\Delta$ & $x$ \\
\hline & 42.1 & 0 & 0 & 0 & $\Delta$ & $\Delta$ & $x$ & $\Delta$ & $x$ \\
\hline & 50 & 0 & 0 & 0 & $\Delta$ & $\Delta$ & $x$ & $\Delta$ & $x$ \\
\hline
\end{tabular}

表-4 各項目の影響

\begin{tabular}{|l|c|c|c|}
\hline & 親水路流量 & スリット流量 & 全流量（全体流量） \\
\hline 水梁 & $1 / 2$ 乗に比例 & $1 / 2$ 乗に比例 & $1 / 2$ 乗に比例 \\
\hline 親水路管径 & $\begin{array}{c}\text { 比例（流量係数は } \\
\mathrm{d}=28.1 \mathrm{~mm} \text { 作大） }\end{array}$ & 一定 & 一定 \\
\hline スリット前部管長 & 反比例 & 一定 & 一定 \\
\hline スリット長 & 反比例 & 比例 & 比例 \\
\hline スリット後部管長 & 反比例 & 反比例 & 反比例 \\
\hline
\end{tabular}

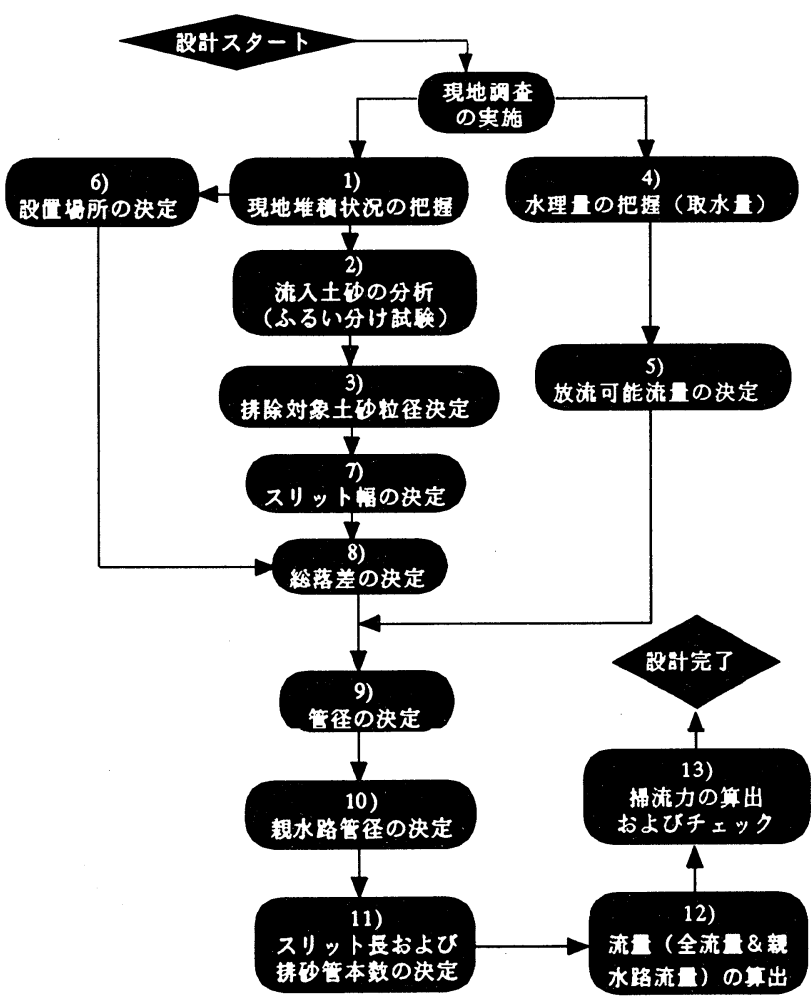

図-12 渦動排砂管設計フロー 
(5)掃流力は, 水深に比例して大きくなり, 帅ッ後部管 長が短いほよ゙大きくなる。

(6)親水路管径 $28.1 \mathrm{~mm}$ で排砂効率が最大である。

(7)親水路付渦動排砂管を設計する場合, 可能な限りス リッ前部管長を短くする必要がある。

(8)親水路付渦動排砂管の性能を発揮できる限界の水ッ 卜長は $1 \mathrm{~m}$ である。

(9)排砂機能確認試験を行った結果, 杫長 $1 \mathrm{~m}$, 親水 路管径 $28.1 \mathrm{~mm}$ の場合, 親水路付渦動排砂管の機能を 完全に満足したが, 刏悵 $1.22 \mathrm{~m}$ の場合，いずれの ケースも親水路管径に対して排砂管の機能を満足し ない。

\section{7. 钤計フロー}

実験結果から, 親水路付渦動排砂管の各諸元の決 定方法は, 以下に示すとおりである。図-12に親水路 付渦動排砂管形状の決定までのフロー ${ }^{3)}$ を示す。

\section{(1)現地堆程状況の把提}

現地堆積状況の把握は, 排砂管の設置場所を決定 する際に利用するので, 発電停止した後の排砂作業 前に行う。その時に行う事は, 1)土砂堆積状況観察(沈 砂池および取水口上流部の様子を含む)，2)土砂採取

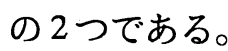

\section{(2)流入土砂の分析（ふるい分け试験）}

土砂採取を行った後にふるい分け試験を行い，流 入土砂の粒度分析を行い, 累加重量百分率, $\mathrm{d}_{50}, \mathrm{~d}_{65}$, 細骨材の比重および吸水率を算出する。また, 流入土 砂の比重も算出する。

\section{(3)排除対鱼土砂柆径の決定}

対象土砂粒径は,現地堆積状況および採取した土砂 の累加重量百分率から判断する。土砂が大量に堆積 している地点を対象に排除対象土砂粒径を算定する。

\section{(4)使用水至の把握}

沈砂池の使用水量, 河川維持流量の大小により, 排 砂管1本あたりの放流可能流量を決定するので, 使用 水量の值は必ず把握する。

\section{(5)放流可能流兵の設定}

排砂管一本当たりの放流可能流量は, 発電に支障 のない範囲で設定する。使用水量の $3 \%$ ～5\% 程度に 設定すれば良いと考えられる。

\section{(6)設置場所の決定}

設置場所は現地堆積状況から判断して決定する。

\section{(7)スリット湢の決定}

刏ッ始端幅と则ット終端幅の比は, 刏ッ始端幅:スリッ

卜終端幅 $=2: 1^{4)}$ とする。

沈砂池内部に木の葉および木の枝が流入する可能
性を有する場合，目詰まり防止の観点からスリッ始端 幅は $20 \mathrm{~mm}$ 以上，終端幅は $10 \mathrm{~mm}$ 以上とする。

\section{(8)㥹落美の決定}

総落差Hの算定方法は, 沈砂池内の水面高さから 渦動排砂管出口部の管断面中心高さの差とする。

\section{(9)管径の決定}

刏ッ管径は，放流可能流量（使用水量の 3\%～5\% 程度）と総落差から決定する。

\section{(10)親水路管彺の決定}

親水路管径は, 刏ッ管径の 60\% とする。なお，塩化 ビニール管や鉄管の管径のサイズが計算で求めたサ イズと一致しない場合, 計算で求めた親水路管径に 最む近いサイズを使用する。

\section{(11)スリっト長および排砂管本数の決定}

杊ット長は，現地観察の状況把握結果から土砂排除 を行いたい幅を算出し，それを则ッ長とするが, 沈砂 池の幅が広く，1 本の渦動排砂管でまかないきれな い場合，複数本の渦動排砂管を配置する。

\section{(12)流旦（全流＆\&親水路流旦）の年出}

全流量および親水路流量は, 図-7,8から流量係数を 求め, 式(1), 式(2)に代入して算出する。

\section{(13)擩流力の萛出およびチェック}

刏ッ始端部掃流力は, (12)で算出された流量係数の 值を式(9)に代入して算出し，その值を限界掃流力と 比較し掃流力をチェッする。

\section{8. あとがき}

現在, 当社管内において渦動排砂管を設置した地 点の運用状況は, パトロール時のみの排砂作業では, 急な 出水により大量の土砂が沈砂池内に流入した場合, 渦動排砂管の機能が低下する事態に陥る場合がある。 そのため, 土砂流入を検知した時点で自動でバルブ を開閉するシステムなど, 渦動排砂管機能低下を防 止するシステムを考案する必要がある。

\section{9. 等文嘼}

1)吉良八郎: ダムの堆砂とその防除,森北出版, 1982.9

2)荒木正夫: 刏帅管の水理に関する一考察, 土木学会誌, 413, PP107-112,1956

3)熊谷洋: 沈砂池排砂機構に関する研究,東北電力(株)研究開 発センター報告No.98004, 1998.7

4)佐々木牧夫: 沈砂池排砂方法の検討に関する研究,東北電 力(株)技術研究所報告(依頼研究報告) No92001, 1992. 